\title{
Changing impacts and societal responses to drought in southwestern Germany since 1800
}

\author{
Mathilde Erfurt $^{1}$ (D) $\cdot$ Rüdiger Glaser $^{1} \cdot$ Veit Blauhut $^{2}$ \\ Received: 15 December 2018 / Accepted: 1 June 2019 / Published online: 22 June 2019 \\ (C) The Author(s) 2019
}

\begin{abstract}
Drought directly and indirectly affects the entire socio-economic and environmental sectors in southwestern Germany. Such impacts are a result of the drought hazard and an underlying vulnerability of the systems. With respect to climate change and the dynamics of vulnerability over time, it becomes crucial to investigate the preceding components, in order to understand possible future magnitudes of the hazard and drivers of drought impacts. Therefore, drought indices were generated from the early nineteenth century in order to identify exceptional meteorological summer droughts. Documentary evidence and historical yield statistics were used to contextualise historical drought events by drought impacts and responses. Considering both, selected summer drought events were analysed and mutually compared based on the impact on society and ecology, as well as societal responses to these. The derived standardised indices highlight differences between severe droughts in duration and temporal peculiarity and put into perspective the current understanding of the intensity of recent drought hazards. The discourse analysis reveals that the propagation of drought and the kinds of impacts have remained rather similar through time, only shifting to modern livelihood assets. However, vulnerability, which strongly depends on the societal contexts, has changed over time and lowered severity of impacts, especially with regard to food and water supply, as well as human health.
\end{abstract}

Keywords Drought impacts $\cdot$ Documentary data $\cdot$ Societal responses $\cdot$ Drought indices

\section{Introduction}

Droughts can cause severe impacts on economic, social and environmental systems (Stahl et al. 2016). These impacts are driven by the combination of drought as a hazard and the underlying vulnerability of social-ecological system of

Mathilde Erfurt

mathilde.erfurt@geographie.uni-freiburg.de

Rüdiger Glaser

ruediger.glaser@geographie.uni-freiburg.de

Veit Blauhut

veit.blauhut@hydrology.uni-freiburg.de

1 Physical Geography, Institute of Environmental Social Science and Geography, Faculty of Environment and Natural Resources,

University of Freiburg (Germany), Schreiberstr. 20,

79085 Freiburg, Germany

2 Environmental Hydrological System, Faculty of Environment and Natural Resources, University of Freiburg (Germany), Fahnenbergplatz, 79085 Freiburg im Breisgau, Germany interest itself (Blauhut et al. 2016). In order to reduce future drought impacts and to foster today's drought risk management, it is essential to understand the drivers of past drought impacts (Van Lanen et al. 2016; Kreibich et al. 2019).

The hazard of drought is a complex phenomenon that generally results from a lack of precipitation and/or an increased evapotranspiration, which can propagate through the hydrological cycle. Accordingly, meteorological drought precedes soil moisture drought, which precedes hydrological drought as a frame for reduced stream flow, groundwater levels, lakes and ponds (Wilhite and Glantz 1985; Van Loon 2015; Wilhite and Pulwarty 2017). Beyond the hazard, vulnerability to drought typically characterises the social, political, technological and cultural contexts of the systems investigated (De Stefano et al. 2015; González Tánago et al. 2016; Blauhut et al. 2016).

To characterise the hazard, drought research developed a wealth of different drought indices (Zargar et al. 2011). In order to identify larger-scale changes of drought, the majority of studies investigate trends since the 1950s (e.g. Sheffield et al. 2012; Orlowsky and Seneviratne 2013; Spinoni et al. 2015). Only a few consider longer instrumental time series 
(e.g. Andreadis et al. 2005; Dai 2011). Nevertheless, Hannaford et al. (2013) showed that the length of the study period and the point of time of investigation have a strong influence on detected strengths and directions of trends. The application of a longer time series will lower the risk of underestimating future events (Benestad 2003).

Comparably, little is known about temporal changes in vulnerability and exposure to drought, which is mainly due to a lack of consistent data (Kreibich et al. 2019). To substitute for the lack of information, drought impacts can be applied as a proxy for past vulnerability (Blauhut et al. 2015a). To establish a long time series of drought impact data documentary evidence, like annals, town chronicles, public announcements, newspaper and official reports, can be used as drought relevant sources (GilGuirado et al. 2016; Stahl et al. 2016; Brázdil et al. 2018). Furthermore, a growing number of studies are using longterm precipitation data alongside documentary evidence in order to better understand past drought events. Noone et al. (2017) developed a 250-year historic drought catalogue for Ireland, using reconstructed precipitation series from 1765 and documentary evidence (mainly newspapers) to gain insight into the socio-economic impacts of drought events. Brázdil et al. (2013) reconstructed drought in the Czech Lands from 1090 to 2012, also using instrumental data and documentary evidence. Nash et al. (2019) identified drought events in southeast Africa including newspapers, colonial and missionary materials.

Nevertheless, databases which pool textual information on past drought conditions and impact are scarce. Thus, Stahl et al. (2016) developed the European Drought Impact report Inventory (EDII) database which pools and categories reported information on drought impacts in Europe since 1900. The EDII focuses on the negative environmental, economic or social effects experienced under drought conditions. The collaborative virtual research environment tambora.org provides original text quotations on climate events such as droughts, floods and other climatic information since 1000 A.D., along with their societal impacts and responses (Glaser et al. 2015).

Considering collected drought impact information of the EDII, Baden-Württemberg has been impacted by drought for a variety of sectors, showing a comparably high drought risk for the hydrological sectors of energy and industry, public water supply and water quality (Blauhut and Stahl 2018). However, the applied time series only extend back to the 1970s.

Climate change projections show Baden-Württemberg in an area of uncertain predictability of how climate change will have an impact (Stagge et al. 2015). Regional investigation claims drier and warmer summers with an accordingly higher likelihood of drought occurrence (KLIWA 2009). Since clear statements on eventual trends remain questionable, the importance of analysing past conditions becomes evident.
A number of studies have begun to examine and evaluate the linkage of drought indicators with drought impacts (e.g. Bachmair et al. 2016; Blauhut et al. 2015a). However, few studies have investigated the change of impacts and responses through time (Kreibich et al. 2019). The objective of this study is to characterise historical summer drought events by quantifying the intensity of the hazard, assessing related past drought impacts and human responses, and to evaluate the societal contextualisation within southwestern Germany, i.e. modern Baden-Württemberg. In essence, the underlying vulnerabilities of the time are discussed as possible drivers of the dynamic character of drought impact and response occurrence.

\section{Data and methods}

In Fig. 1, the underlying methodological concept is outlined. A combination of quantitative and qualitative approaches was used to enhance the understanding of drought hazard and their impacts and responses within southwestern Germany, the modern state of Baden-Württemberg.

Previous studies have suggested that analysis of the drought hazard should be linked with an assessment of vulnerability and vice versa (e.g. De Stefano et al. 2015; Glaser et al. 2018). Accordingly, instrumental records had been used to derive drought indices and to identify the most extreme drought events since 1800. Precipitation deficit triggers meteorological drought which can propagate to soil moisture and hydrological drought (e.g. Wilhite and Pulwarty 2017; Van Loon 2015). Hence, the major focus of drought hazard analysis is on precipitation, but summer heat wave effects are attributed from temperature information. Documentary and socio-economic statistical data were used to analyse drought impacts and societal responses.

\section{Drought hazard}

\section{Monthly precipitation and temperature records}

Drought occurrence, here defined as severity of precipitation shortfalls, is analysed based on a selection of long-term precipitation records across Baden-Württemberg. Table 1 gives further information on the historical measurement stations. The selected stations have monthly precipitation records that cover the temporal extent between the beginning of the nineteenth century until the year 2018 (some exceptions), (b) cover the study area spatially and (c) contain only a few missing values. Historical records stem from the Historical Instrumental Climatological Surface Time Series Of The Greater Alpine Region-Project (HISTALP, Auer et al. 2007), which processed and homogenised long-term climate time series datasets for the Greater Alpine Region. Five stations: 
Fig. 1 Methodological framework

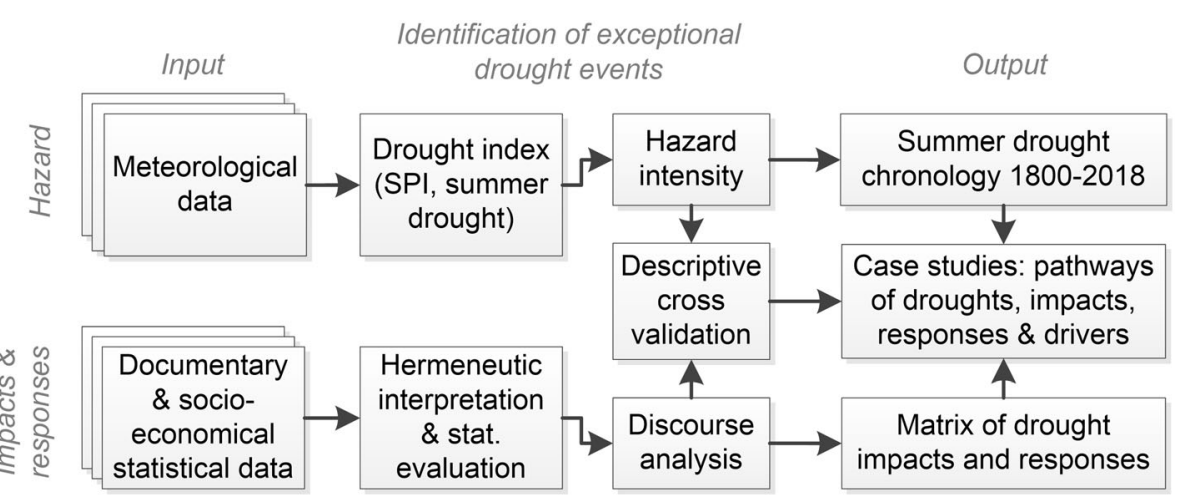

Freiburg im Br., Rheinstetten, Ulm-Giengen, StuttgartSchnarrenberg and Konstanz-Meersburg-Friedrichshafen were selected (the last is a composition of three stations). Where available, monthly temperature averages were also selected. The datasets cover a time period from the year 1801 until 2015. For the purpose of this paper, the time series were updated until the year 2018, where possible, using data from the Deutscher Wetterdienst (DWD).

\section{Drought indices}

A wealth of nearly 150 different drought indices exists, which reflects the variety in drought definitions (Zargar et al. 2011). The most prominent and WMO recommended drought index is the Standardised Precipitation Index (SPI, McKee et al. 1993; Guttman 1999; Lloyd-Hughes and Saunders 2002; Svoboda et al. 2012; Spinoni et al. 2015). The SPI relies only on monthly precipitation data, which makes it ideal for studying droughts in the past, where data availability is one of the limiting factors. The SPI can be applied for different time scales and therefore be used to reflect meteorological, soil moisture and hydrological drought anomalies.

The computation of the SPI was performed using the $\mathrm{R}$ Package "SPEI" (Version 1.7) from Beguería and VicenteSerrano (2013), using the gamma distribution to define the relationship of probability to precipitation. Parameter fitting was based on unbiased probability weighted moments. Values below zero indicate dry periods, and values above indicate wet periods. To indicate long-term changes in drought frequency and intensity, the reference period was set to the longest available duration at all stations 1870-2010. The SPI was then calculated for the accumulation periods 3, 6, 9 and 12 months.

Focusing on summer droughts, accumulation periods for different times of the year were selected to cover the warmest summer month, main growing season, vegetation period and the annual average (SPI-3 for August, SPI-6 for September, SPI-9 for October, and SPI-12 for December). The SPI was classified according to the US drought monitor (National Drought Mitigation Center 2018): D4 = exceptional drought with SPI values below -2 . D3 $=$ extreme drought with SPI from -1.6 to $-1.99, \mathrm{D} 2=$ severe drought with from SPI -1.3 to $-1.59, \mathrm{D} 1=$ moderate drought with SPI from -0.8 to -1.29 . D0 stands for an abnormally dry period with values between -0.5 and -0.79 .

In order to identify possible heat wave effects on summer droughts, the Standardised Temperature Index (STI) for the accumulation period of 3 months (June to August) was calculated following the same procedure.

\section{Drought impacts and responses}

\section{Documentary sources}

Early historical drought events are evaluated on the basis of contemporary documents, in particular town chronicles,

Table 1 The locations and time spans of long-term monthly precipitation and temperature records used in this study. - no data available. Dataset: Histalp (Historical Instrumental Climatological Surface Time Series of the Greater Alpine Region, Auer et al. 2007)

\begin{tabular}{|c|c|c|c|c|c|c|c|c|}
\hline \multirow[b]{2}{*}{ Name } & \multirow[b]{2}{*}{ Acr. } & \multirow[b]{2}{*}{$\mathrm{x}\left({ }^{\circ} \mathrm{E}\right)$} & \multirow[b]{2}{*}{$\mathrm{y}\left({ }^{\circ} \mathrm{N}\right)$} & \multirow[b]{2}{*}{ Altitude (m) } & \multicolumn{2}{|c|}{ Precipitation } & \multicolumn{2}{|c|}{ Temperature } \\
\hline & & & & & Beginn & End & Beginn & End \\
\hline Rheinstetten-Karlsruhe & RH & 8.29 & 48.96 & 118 & 1801 & $2018^{\mathrm{a}}$ & 1801 & $2018^{\mathrm{a}}$ \\
\hline Stuttgart-Schnarrenberg & ST & 9.20 & 48.83 & 314 & 1807 & $2018^{\mathrm{a}}$ & 1807 & $2018^{\mathrm{a}}$ \\
\hline Ulm-Giengen & UL & 9.95 & 48.38 & 567 & 1822 & 2013 & 1868 & 2010 \\
\hline Freiburg im Breisgau & FR & 7.83 & 48.00 & 300 & 1870 & $2018^{\mathrm{a}}$ & 1870 & $2018^{\mathrm{a}}$ \\
\hline Konstanz-Meersburg-Friedrichshafen & $\mathrm{KO}$ & 9.18 & 47.67 & 443 & 1827 & 2012 & - & - \\
\hline
\end{tabular}

${ }^{\mathrm{a}}$ Updated with data from the DWD (Deutsche Wetterdienst) 
annals, diaries and newspaper reports (e.g. Freiburger Zeitung 1834a, 1834b,1834c, 1834d ; Pfaff 1846; Badische Neueste Nachrichten 1947a, 1947b, 1949a, 1949b; Dürr 1986; Nees and Kehrer 2002), as available in the collaborative Historical Climate and Environmental Database tambora.org. In addition, public announcements, governmental reports, annual harvest and weather reports were used, including quantitative data such as population development, crop yields or pricing (e.g. Württembergisches Jahrbuch für Statistik und Landeskunde 1830; Borcherdt et al. 1989). For the more recent events from the twentieth century onwards, an increasingly wide range of information can be drawn upon, including reports from the Allied Control Council, scientific papers and reports of non-governmental agencies. The rising variety of sources is accompanied by an increasing diversity in media sources such as film documentaries, photos and interviews with contemporary witnesses. Furthermore, drought impacts and its responses since the 1970s are complemented by information of the EDII (Stahl et al. 2016).

\section{Discursive assessment of drought impacts and responses}

The likelihood of drought impact occurrence, drought risk, is in a very general sense, a function of the hazard and the underlying vulnerability of the systems of interest (Blauhut et al. 2016). Hereby, the definition of vulnerability to drought and its components depends on different criteria, but, basically includes components of exposure, sensitivity and adaptive capacity (González Tánago et al. 2016). Accordingly, reported drought impacts can be treated as proxy of past hazard and vulnerable conditions (Blauhut et al. 2015a). For this study, the risk concept is regarded as a pathway in which drought hazards cause negative socio-economic and environmental impacts as well as societal responses and adaptation measures. The event-specific occurrence of these variables reveal society's resilience to drought and the changing complexity of societies during the industrialisation, the modern period and the specific post war situation.

While hazard characteristics can be evaluated on the basis of the instrumental records, aspects of drought impacts and corresponding human responses can be derived e.g. from written documents, photos and other information. The given information was assessed on the basis of hermeneutic principles of critical source analysis (Glaser 2013). Further aspects of vulnerability, such as political situation and population distribution, are gathered from historical context. Following a discursive assessment, the diverse descriptive sources regarding the impacts and responses are summarised in a generalised impact and responses matrix. Finally, the selected drought events are contrasted in a comparative table, characterising event-specific hazard, impact and societal responses.

\section{Results}

\section{Severe drought events in southwestern Germany}

An overview of major summer drought events in southwestern Germany since 1800, characterised by different accumulation periods of SPI, is given in Fig. 2. A trend of a general increase or decrease of drought event occurrence over the period of investigation is not identifiable. Nevertheless, clusters of increased incidence of severe drought events between 1830 and 1842,1860's, 1920s, 1945 and 1960, and from 2003 onwards, are evident. In contrast, 1800-1830, 1845-1855 and 1965-2000 show only few drought events.

For the analysis, droughts that were categorised as D3 or D4 droughts at more than two locations and more than two accumulation periods were selected. According to these criteria, the following drought event years were identified: 1832, 1834, 1842, 1865, 1884, 1887, 1911, 1919, 1921, 1923, 1928, 1947, 1949, 1964, 1991, 2003, 2015 and 2018. In order to limit the amount of events for analysis, we chose case study events for certain historical and political phases. The 1834 event was selected for the phase of early industrialisation in Germany. The year 1865, marked by an exceptional drought, was selected as an event where Germany's industrialisation was at a high point. During the Weimar republic (designation for the German state from 1918 to 1933), the 1921 drought was selected. For the post-warsituation after the World War II, the years 1947 and 1949 were selected as case studies. As more recent drought events 2003 and 2018 were chosen for analysis.

Table 2 lists the top five drought events per station in terms of their SPI value per accumulation time scale. Because of the different lengths of the precipitation time series, the top five events cannot necessarily be compared (Table 1). Nevertheless, from the data in Fig. 2 and Table 2, it is apparent that the summer, the vegetation period and the annual average of 1949 were exceptionally dry. The summers of 2003 (in FR) and 2018 (RH, FR) are also among the top five droughts. Considering a 6-month accumulation time scale, the summer half-years of 1834 (UL, ST, KO), 1865 (RH, KO), 1947 (FR), 2003 (RH) and 2018 (RH, FR) are listed as top five events. In the years 1921 (UL, ST), 1947 (FR), 1949 (UL, ST, KO, FR) and 2018 (FR), the vegetation period was also one of the driest in Baden-Württemberg since 1800. On an accumulation period of 12 months, the years 1834 (ST), 1865 (ST, KO), 1921 (UL, ST, RH), 1949 (UL, KO, FR) were marked as top five events.

\section{The drought impact and responses matrix}

The diversity of drought impacts and corresponding responses in the study area is summarised in a generalised manner in Fig. 3. The matrix is derived from contextual content of the 


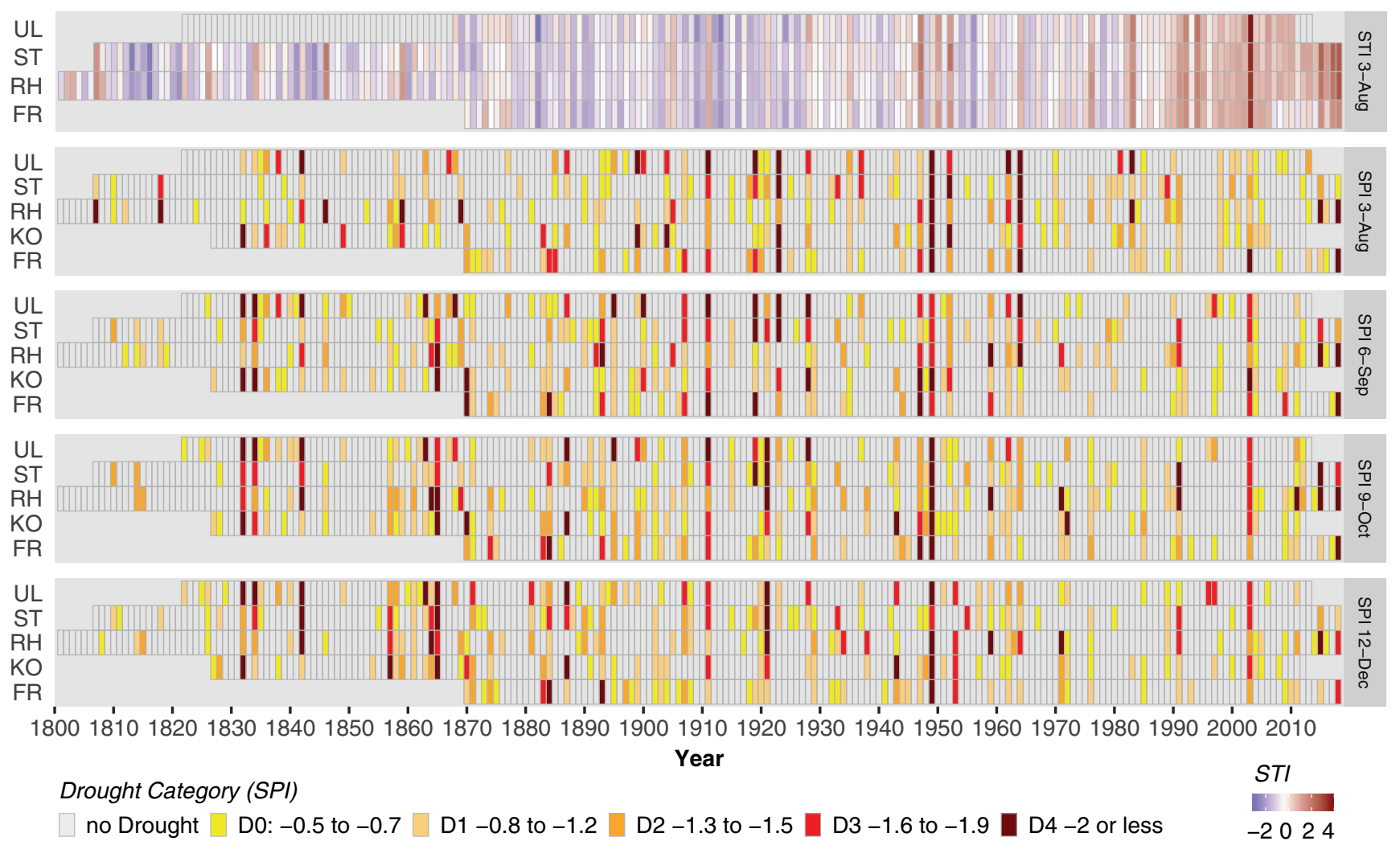

Fig. 2 Drought development on different time-scales for measuring stations in Baden-Württemberg (UL: Ulm-Giengen, ST: StuttgartSchnarrenberg, RH: Rheinstetten, KO: Konstanz-MeersburgFriedrichshafen, FR: Freiburg im Breisgau). The y-axis shows the Standardised Precipitation Index (SPI) values for different accumulation

original quotations and documents, which have been categorised into impacts and responses to the sectors of ecology, health, economy, governance and societal situation. It therefore can be regarded as a checklist for the discourse analysis. It comprises the initial climatic stressors of the hazard, such as a lack of rainfall and high temperature, which can propagate to a soil water deficit and hydrological drought (Wilhite 2000). Drought impacts mainly occur for the sectors of ecology, food security, human health and economy, whereas the majority of responses are documented for the sectors of governance and society.

\section{Selected drought events}

\section{Drought events during the industrialisation}

The drought event of 1834 was classified as a D2 to D4 drought for all investigated sites on the SPI accumulation periods 6 (Sep), 9 (October) and 12 (December) (Fig. 2). The instrumental records are underlined by textual evidence, where rich and high-quality grape harvest and low water levels were documented (Pfaff 1846). Furthermore, written sources near Lake Constance report poor hay and potato harvests due to drought. periods. SPI values are coded according to severity thresholds shown in the legend. The STI (Standardised Temperature Index) value is shown for an accumulation period of 3 months for August. Database: Histalp (Historical Instrumental Climatological Surface Time Series of the

Due to the drought-induced shortage of livestock feed and straw, the Royal Ministry of Finance near Stuttgart ordered that the grass in the state forests should also be used as fodder (Freiburger Zeitung 1834a, b). In Upper Swabia, livestock was reported to be extremely cheap and hay extremely expensive (Freiburger Zeitung 1834b). As impacts of hydrological drought, some stream mills stood completely still (Freiburger Zeitung 1834c), hydropower stations (e.g. sawmills) suffered financial losses due to a lack of stream flow (Freiburger Zeitung 1834d), the water level of Lake Constance was lower than any inhabitant had ever seen before, and many springs were completely dried up. Mice and locust plagues had occurred in the neighbouring region of Frankfurt and surroundings. Furthermore great hardship because of the drought was reported, as well as the lack of water for hygiene, washing and cleaning. The few wells, still having water, had been beset by people around the clock (Nees and Kehrer 2002).

During the drought of 1865 , strong impacts on the sectors of agriculture, forestry and industrial production, which were still largely dependent on water and hydro energy, were reported. The lack of food in 1865 led to malnutrition, but thanks to the improved infrastructure, larger-scale, partly even international food imports, could be organised to lower the 
Table 2 Top five drought events per station in terms of their SPI (Standardised Precipitation Index) value per accumulation time scale. Stations: UL: Ulm-Giengen, ST: Stuttgart-Schnarrenberg, RH:
Rheinstetten, KO: Konstanz-Meersburg-Friedrichshafen, FR: Freiburg im Breisgau). Selected case studies are in italics (for more information on the stations see Table 1)

\begin{tabular}{|c|c|c|c|}
\hline Acc. period & Year of occurrences & Station & SPI value \\
\hline \multirow[t]{5}{*}{3 months (Jun-Aug) } & $1949,1923,1911,1962,1842$ & UL & $-3.94,-2.81,-2.61,-2.49,-2.30$ \\
\hline & 1923, 1952, 1949, 1964, 1911 & ST & $-2.69,-2.48,-2.27,-2.05,-1.89$ \\
\hline & $1983,1949,1846,2018,1818$ & RH & $-3.08,-2.65,-2.52,-2.36,-2.24$ \\
\hline & 1949, 1899, 1904, 1952, 1832 & $\mathrm{KO}$ & $-3.58,-2.66,-2.32,-2.16,-2.14$ \\
\hline & $1949,2018,2003,1964,1923$ & FR & $-3.08,-2.54,-2.27,-2.17,-2.03$ \\
\hline \multirow[t]{5}{*}{6 months (Mar-Sep) } & $1842,1928,1834,1923,1911$ & UL & $-3.79,-2.87,-2.83,-2.73,-2.66$ \\
\hline & $1919,1923,1834,1911,1928$ & ST & $-2.55,-2.07,-1.98,-1.98,-1.98$ \\
\hline & $2018,1865,1893,1859,2015$ & RH & $-2.48,-2.28,-2.13,-2.06,-2.06$ \\
\hline & $1870,1832,1834,2003,1865$ & $\mathrm{KO}$ & $-2.95,-2.91,-2.55,-2.37,-2.27$ \\
\hline & $1947,1884,1870,2018,1919$ & FR & $-2.95,-2.79,-2.34,-2.19,-2.14$ \\
\hline \multirow[t]{5}{*}{9 months (Feb-Oct) } & $1842,1832,1863,1949,1921$ & UL & $-3.60,-2.98,-2.91,-2.58,-2.51$ \\
\hline & $1919,1921,2015,1949,1991$ & ST & $-2.56,-2.45,-2.27,-2.19,-2.16$ \\
\hline & $2018,2015,1959,1991,1971$ & $\mathrm{RH}$ & $-3.12,-2.82,-2.50,-2.47,-2.40$ \\
\hline & $1832,1949,1870,1943,1887$ & $\mathrm{KO}$ & $-3.51,-2.82,-2.25,-2.13,-2.12$ \\
\hline & $1884,2018,1949,1947,1893$ & FR & $-2.96,-2.53,-2.43,-2.16,-1.94$ \\
\hline \multirow[t]{5}{*}{12 months (Jan-Dec) } & $1842,1863,1921,1949,1832$ & UL & $-3.41,-3.28,-2.68,-2.54,-2.48$ \\
\hline & $1921,1865,1842,1884,1834$ & ST & $-2.73,-2.64,-2.03,-1.95,-1.89$ \\
\hline & $1864,1959,1971,1842,1921$ & RH & $-2.99,-2.48,-2.40,-2.36,-2.16$ \\
\hline & $1832,1887,1865,1949,1857$ & $\mathrm{KO}$ & $-3.44,-2.73,-2.69,-2.53,-2.29$ \\
\hline & $1884,1949,1893,1883,1953$ & FR & $-2.81,-2.03,-2.00,-1.98,-1.98$ \\
\hline
\end{tabular}

impact (Dürr 1986). The organisation of soup kitchens, collections and fundraisings also reached a new height. The threat of epidemics was tackled by filtering the water or disinfecting houses, but in some areas, limited hygiene caused epidemic breakouts such as cholera. The casualties had to be buried in mass graves (Nees and Kehrer 2002).

\section{Drought of 1921 during the Weimar Republic}

According to the SPI accumulation period of 12 months, the year 1921 stands out as an exceptional drought. Only considering the SPI-3 from August reveals that the summer was mainly classified as abnormally dry to moderate dry (Fig. 2). The agrarian and forestry impacts, as well as the hydrological impacts, followed the typical propagation of early blossoming, early ripening and harvesting, harvest failures, dried-up wells and springs. Low water levels in major rivers had been reported and forest fires had occurred. Smaller villages which run out of water had to be supported via water tankers. The inadequate water supply peaked in the beginning of August, where authorities imposed water usage restrictions. People suffered from heat stress and heat strokes. Plagues of mice and flies appeared and worsened the situation (Nees and Kehrer 2002). In comparison, the mitigation of drought impacts of 1921 did not differ much from the examples of the nineteenth century. However, political changes resulted in a lower vulnerability to the hazard. Better governance in the sense of organisational structure, advanced technical capabilities, improved medical support, faster communication and an increased infrastructure, led to an increased resilience. Nevertheless, the degree of reduced vulnerability at the beginning of the twentieth century was limited by the burdens and reparations of the aftermath of the First World War.

\section{Droughts of 1947 and 1949 in Post-War Germany}

The years after World War II were marked by two subsequent extreme drought events in 1947 and 1949 (Fig. 2). Regarding the lack of precipitation, the year 1949 was more extreme than 1947. In contrast, the documented impacts of the drought of 1947, which was called the "steppe summer", were much worse (Fig. 4, Badische Neueste Nachrichten 1947a), not least because of the previous extremely cold winter of 1946/47, named the "hunger-winter". In addition, the drought occurred at a time when the population of Germany was dealing with the consequences of World War II: a lack of housing, destroyed infrastructure, lack of workers, millions of displaced people and refugees (Badisches Ministerium der Finanzen 1948).

The lack of rain led to large-scale agricultural losses. However, unusual regional differences, due to the lack of fertilizer and different cultivation techniques were reported. In 


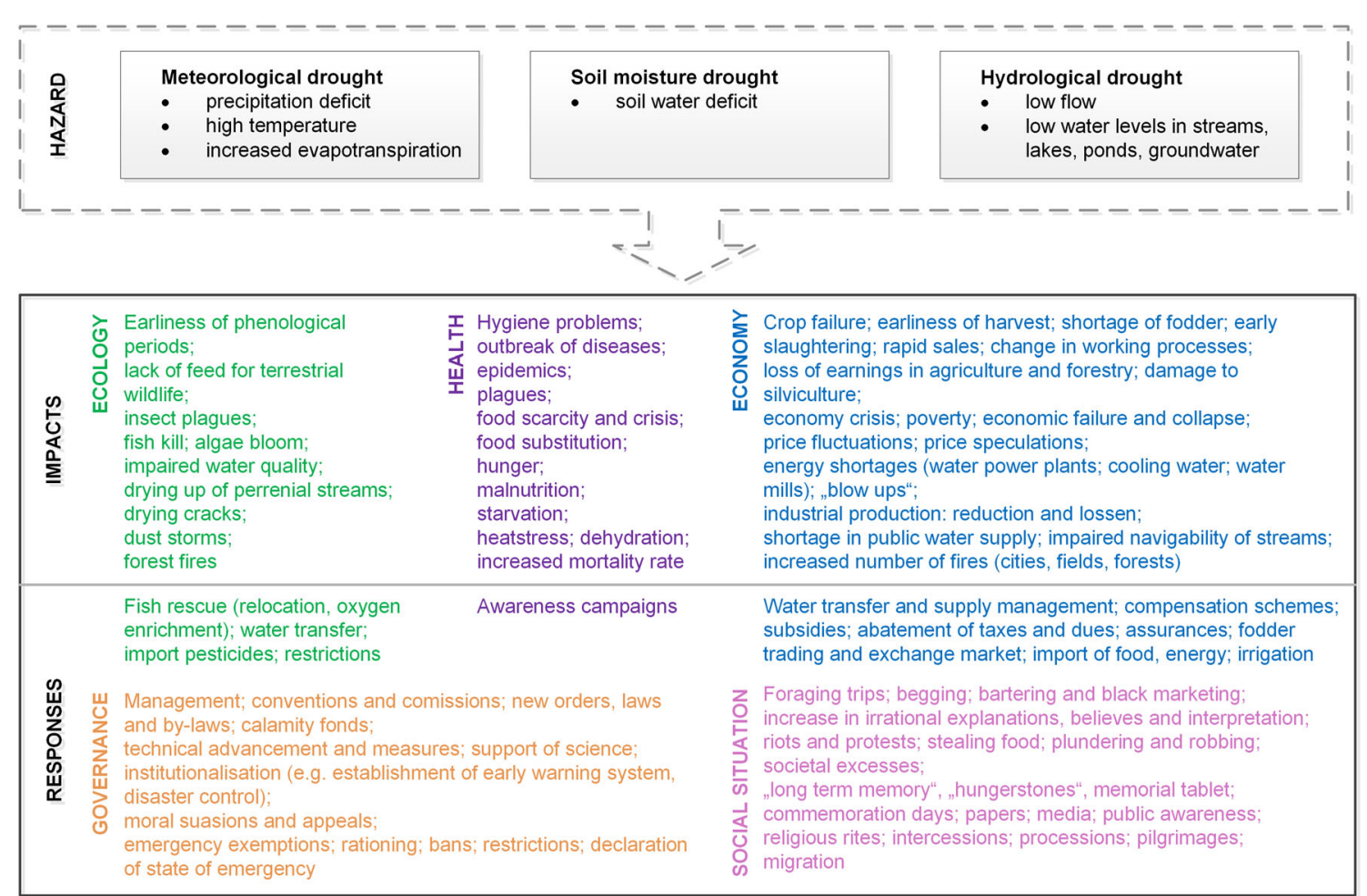

Fig. 3 Matrix of drought impacts and responses in southwestern Germany derived from contextual content of the original quotations and documents

addition, pests appeared in many places. Forest damage arose, particularly on spruces due to small growths and pests (Bender 1948; Geiger 1951). The drought favoured the ignition of fires in forest, meadow and moorland areas. Groundwater levels dropped in many places, springs dried up, many streams and larger tributaries carried little or no water at all. Hunger stones became visible in the river Rhine; a plethora of fish died. Shipping on the Middle Rhine and on the Danube was temporarily suspended. On the sandy soils of the Upper Rhine region, the strong winds led to dust plagues and to deep and extensive dry cracks in the soil (Deutscher Wetterdienst in der US-Zone 1947; Nees and Kehrer 2002). Water-operated mills and sawmills stood still. Southwestern German hydropower plants had to cut down on their operations significantly; the power supply was regionally shut down and drastic cuts in power consumption were imposed. This resulted in extensive plant shutdowns and severe production losses. Finally, drinking water became scarce and health problems were reported (Heyn 1981). Settlements of higher altitudes did not receive water for weeks; water had to be transported several kilometres by wagons. Individual adaptation strategies included relocating (foraging trips), bartering and black marketing, as well as stealing food. The Allied Control Council reacted to the lack of water in the hydroelectric power plants by rationing food and power supplies as well as by cancelling trains, while labour productivity also declined (Badische Neueste Nachrichten 1947b). People started to protest against the restrictive food supply and it was not until the end of the year 1947 that food imports were allowed again. School meals were then organised and the respective occupying powers began providing relief supplies (Deutscher Wetterdienst in der US-Zone 1947).

In the summer 1949 (SPI-3 for August), an exceptional drought occurred throughout the whole state (Fig. 2). Also, the vegetation period from February to October (SPI-9 for October) was classified as an exceptional drought event. Table 2 shows that the summer, the vegetation period and the whole year are listed among the top five drought events, considering a timeframe of 150 to 200 years. The impacts followed the same "classical" pathway: The lack of rainfall led to a significant drop in harvest and lack of fodder for livestock (Badische Neueste Nachrichten 1949a)—especially regions with sandy soils had been affected. Large dust veils had been reported, as well as plagues of mice and potato beetles (Nees and Kehrer 2002), sinking groundwater level (Badische Neueste Nachrichten 1949b) and forest damages arose (Baumgartner 1950). In contrast to the impacts of the drought event in 1947, no malnutrition and hunger were documented in 1949.

The mentioned years acted as a catalyst for innovations. In the medium term, the establishment of teaching and food gardens was meant to buffer the latent lack of food. After the dry year of 1949, the concept of the regional water supply pipeline systems, based on Lake Constance, was discussed for the first 


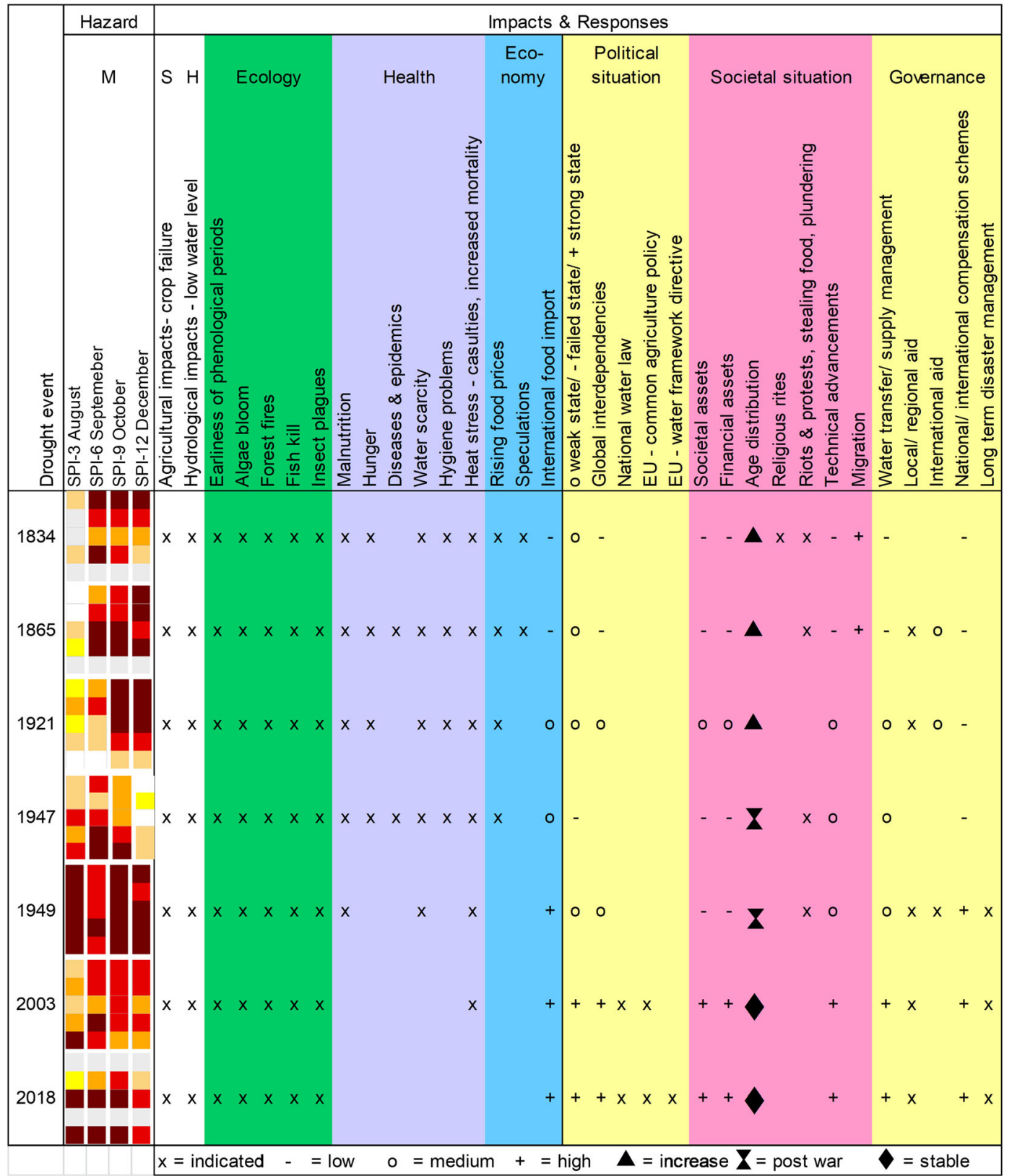

Fig. 4 Compilation of major drought hazard years in southwestern Germany since 1800 and their impacts and responses. M: Meteorological drought hazard for the stations Ulm-Giengen (top),
Stuttgart-Schnarrenberg, Rheinstetten, Konstanz-MeersburgFriedrichshafen, Freiburg im Breisgau (bottom); S: soil moisture drought; H: Hydrological drought. time. In the following year (1950), a study-Commission for water supply had been established and in 1953, the planning commission was started.

\section{The summer of 2003 and its unexpected impact}

As shown in Fig. 2 (STI), the drought of 2003 was strengthened by a lasting heat wave over the summer months. The hazard hit a relative resilient, socio-politically stable society with high financial resources, good governance, political stability and very advanced technical capabilities. The scenario set in motion by the heat and drought initially followed the typical pattern of reduced agricultural production, but in contrast to previous drought events, no food supply problems or hunger occurred. However, bark beetles proliferated massively, severely damaging the forests. Large river systems suffered such an extreme low flow that historical hunger stones reappeared, while even smaller streams dried up completely. The low water levels affected shipping, as well as the cooling of power plants, which in turn had to reduce their production. 
Although groundwater levels dropped in many places and springs and wells dried up, water supply was never threatened and water withdrawal was only restricted in some places. At the same time, the tourist and leisure industries posted record sales. This summer, however, had its own unexpected and dismal record of 35,000 to 70,000 heat-related deaths in Europe, including 7000 in Germany (Koppe and Jendritzky 2014). Casualties occurred especially in larger cities, and mainly among the elderly, infants and persons suffering from cardiovascular diseases and care-dependent people. While technical and economic resilience was particularly strong, the event exposes the particular social vulnerability of an ageing and increasingly isolated and more segregated society. This accelerated the establishment of the Heat Warning Service by the German Weather Service in 2005.

\section{8-The most recent drought record with economic impacts}

The summer half-year of 2018 is ranked as a top five event in FR and RH (Table 2). The reported impacts followed the "classical" pathway (Fig. 4). The hydrological impacts can be summarised with low water levels of the major river systems, and partly dry falling of their contributors. Accordingly, low hydropower production and impaired industrial production was reported all over the state. Low flow at the Rhine led to a pause in ferry transportation and impaired water-borne transportation, which as a secondary impact led to increased energy prices in autumn. Furthermore, nuclear power stations had to lower production or shut down and groundwater levels all over the state dropped to critical levels. High water temperatures in combination with low water levels have led to fish kill. In contrast to the nineteenth century situations, the official water supply was not considered critical, since only small selfsupplying communities had to restrict water supply. Driven by the heat, some highways had been affected by concrete blow ups, causing delays due to following speed limits. No waterborne diseases or hygiene problems were reported, but there had also been concerns and reports about the effects of heat stress on working capacities and productivity, and an overall increase in accidents.

The consequences of the drought of 2018 for agriculture were similar to those of previous years of drought. Apart from an above-average harvest of fruits, reduced crop and root crop productions and even full failures were reported. Livestock was sold because of a shortage of fodder and an increase of prices, leading to a drop of market prices for meat. The German Federal Ministry for food and agriculture (2018) declared the drought of the year 2018 as a "weather phenomenon of national dimension" and guaranteed subsidies of up to 340 million euro for farmers with a harvest reduction of $30 \%$ or more. Ecological impacts also followed the general setting: an earliness of all phenological phases - blossom, ripening and harvest dates - and an early defoliation of the deciduous forests in autumn. Some regions suffered from forest fires. Forest damage was estimated to be at least 5.4 billion Euros ( Arbeitsgemeinschaft Deutscher Waldbesitzerverbände 2018).

The drought of 2018 showed a shift of public awareness towards droughts. Especially economic impacts, e.g. rising prices for agricultural products and energy, came along with discussions and debates about subsidies and public financial support especially for the agricultural sector.

\section{Summary of the effects and feedbacks of extreme drought events}

The synthesis in Fig. 4 shows the visual compilation of different SPIs, characterising summer drought, and corresponding parameters of reported impacts and responses for selected drought events. As can be seen, the effects on ecology did not differ in the severe droughts from 1800 onwards. Significant differences arise however in the hunger and health-related aspects. This was relevant in the nineteenth century as well as in the special situations of 1947/49.

The social reactions, such as riots, religious rites or emigration, clearly point to the different features and vulnerabilities of societies in the nineteenth century. On account of global integration and technical developments, hunger and hygiene aspects are no longer an issue for the 2003 and 2018 droughts but are replaced by new social discourses and developments. New vulnerabilities emerged in 2003 when the issues of ageing and insufficient social integration led to many casualties. In 2018, a strong focus was set on ecological issues but also on financial support and protection of the farmers and forest owners who were particularly affected.

The development towards a smart society, from the era of industrialisation, to post-war Germany and our recent modern society gradually changed vulnerability to drought in southwestern Germany. Possible drivers are a higher scientific understanding of natural phenomena, a better infrastructure with new channels, railways, communication with telegraphs, national and international trade, new institutions and data availability, as well as a better organisation of societies. While the agrarian societies were more dependent upon food supply, and the direct effect of success and failure, the discourse of modern and resilient societies is much more related to the economic consequences and the options of pricing, subsidies and public finance support.

In summary, this analysis shows that the major drought and heat events are quite different in their social responses, while the classical, definition-based pathways of meteorological, hydrological and agricultural droughts are very similar. Bridging the gap over time and thus different social structures and systems demonstrates the dynamics of vulnerabilities and resilience. 


\section{Discussion}

\section{Long-term drought hazards revisited}

The reconstruction of drought indices until 1800 revealed the years between 1855 and 1870 , to be the period with driest summers on record in southwestern Germany. The 1865 event occurred on a large scale and has been confirmed by several central-European regional studies with similar temporal resolution investigating droughts in the same timeframe, e.g. for Czech Republic (1805-2012) (Brázdil et al. 2013), the Alpine regions ( 1800-2012) van der Schrier et al. 2007; Haslinger et al. 2018) and for Ireland (1765-2015) (Noone et al. 2017). Furthermore, Glaser et al. (2017) showed that the heat and the harvest failure of 1865 , which resulted in increased prices during the subsequent years, lead to a migration peak from the German Southwest to Northern America.

On a shorter timescale, the herein identified exceptional summer drought events have also been detected by other authors. Briffa et al. (1994) studied summer moisture variability across Europe between the years 1892 to 1991 based on the PDSI. They found that the summer of 1921 was the most extreme summer in Europe, considering the spatial extent of severe drought conditions. Cook et al. (2015) made the same findings using tree-ring reconstructed summer wetness and dryness over Europe. As early as 1922, Brooks and Gkasspoole (1922) investigated the 1921 drought in Britain and found it to be one of the most extreme droughts that had occurred in Britain since the nineteenth century. The study of van der Schrier et al. (2007) reveals that in some parts of the Alpine region, the winter 1921/1922 belongs to the three driest summers in this region (regarding moisture variability between 1800 and 2003). Haslinger et al. (2018) rank 1921 among the top five droughts on a 12-month accumulation scale. Investigating hydrological drought characteristics, Brázdil et al. (2016) demonstrated that the 1947 drought event was one of the most severe events since 1880s in the Czech lands, which led to a wide range of socio-economic consequences and far-reaching political responses. The European Drought Reference Database (Stagge et al. 2013) then highlights the 1975/76 European drought as a major event during the period of 1958-2009, which could not be confirmed by this investigation on summer droughts. Nevertheless, the 2003 summer drought has been detected as well. Haslinger et al. (2018) ranks 2003 among the top five droughts on a 6-month accumulation scale. Spinoni et al. (2015) investigated macroregional drought events at global scale with a reference period of 1952-2016. For northern Europe, only the 1959 event and the "2003 heat wave drought" are classified as extreme drought events. According to the State Institute for the Environment, Measurements and Nature Conservation Baden-Württemberg (Landesanstalt für Umwelt, Messungen und Naturschutz Baden-Württemberg 2019), the 2018 extreme drought year with major precipitation deficit over the vegetation period was accompanied by 3 weeks of heat. Nevertheless, the record level of $>40{ }^{\circ} \mathrm{C}$ in 2003 was not reached. Due to preceding low reservoirs of 2017, the majority of streams but also groundwater levels felt on low flow.

In summary, we argue that the analysis of long time series for southwestern Germany picked up extreme drought events of larger scale, which have been identified by other authors. Nevertheless, a ranking of drought events by intensity is heavily dependent on the time series available. The longer the time series, the more the recent "extremes" have been relativised. However, extreme drought identification is also depending on the drought indices applied. Here, the choice of SPI generally enables comparability to other studies, but the choice of focusing on summer drought events narrows potential interfaces. Thus, frequency and intensity of drought events might change due to period of the year investigated. Furthermore, the spatial resolution is of strong importance as well. Extreme events affect larger scales, but regional drought hazard intensity differs due to regional characteristics, such as hydrogeology, elevation and land use. To fully understand drought events, and to rank their intensity, additional information on past drought impacts is of need.

\section{Potential drivers of drought impacts and responses over time}

The multi-proxy approach used in this study involves quantitative and qualitative procedures and is positioned at the interface of natural sciences and humanities. It should contribute to the systemic understanding of the drought-environmenthuman relationship (van Dijk et al. 2013). Comparable approaches with a similar intention were presented and successfully implemented by Nash et al. (2019), Klein et al. (2018) and Glaser et al. (2018). The reference to risk approaches and discourse analysis was helpful in identifying impacts and responses and presenting them via pathways.

The complexity of the information as well as the density of data increases over time. Types of documentary evidence sources and their character are also changing with time. As a result, the more recent drought events, especially from 1950 onward, can be analysed in a more differentiated way than the older ones. In order to be able to compare the drought events, however, reference was made to the target values of food security and health. All parameters related to these targets, such as harvest results, population and price developments are available as numerical records in the investigation period, so that they can be quantitatively evaluated.

The perception and discourses within society also have an influence on what is documented as a drought impact. Environmental impacts are not a novelty of more recent drought events. Public perception has gradually shifted towards a better ecological understanding, considering that 
droughts in southern Germany are not a threat for human livelihood with respect to food security and water supply anymore. The increased reporting of ecological impacts for recent droughts has also been observed by Blauhut et al. (2015b) at the European scale and might be attributed to major legislative changes (e.g. national water management plans or the water frame directive), which increased public and governmental recognition. Furthermore, better monitoring networks, reporting strategies and public interaction likely enhanced the number of reported ecological impacts.

\section{Conclusions}

The reconstruction of summer drought events revealed that drought has been a recurring event in southwestern Germany over the past 200 years. However, the occurrence and severity of corresponding impacts is not necessarily related to intensity of the drought hazard, but also to the vulnerability of the society. Droughts in southwestern Germany, as reported in textual documents, cause impacts on ecology, economy, health, governance and social behaviour. The hydrological and agricultural impacts of drought remain the same over the centuries. By contrast, the impacts on societies and the societal responses to drought vary significantly with time depending on the structure, organisation and assets of the individuals and groups.

Considering the climate change debate, this study provides valuable input into the understanding of the magnitudes of historical drought hazards, on how changes in vulnerability stimulate the intensity and occurrence of impacts, and on how human responses can lower the impacts of drought.

Acknowledgments The authors would also like to thank the dataset providers HISTALP, ECA\&D and DWD, Michael Stölzle for their advice and support in creating Fig. 2.

Funding information This study was carried out within the interdisciplinary research project DRIeR. The project is supported by the Wassernetzwerk Baden-Württemberg (Water Research Network), which is funded by the Ministerium für Wissenschaft, Forschung und Kunst Baden-Württemberg (Ministry of Science, Research and the Arts of the Land of Baden-Württemberg).

Open Access This article is distributed under the terms of the Creative Commons Attribution 4.0 International License (http:// creativecommons.org/licenses/by/4.0/), which permits unrestricted use, distribution, and reproduction in any medium, provided you give appropriate credit to the original author(s) and the source, provide a link to the Creative Commons license, and indicate if changes were made.

\section{References}

Arbeitsgemeinschaft Deutscher Waldbesitzerverbände (2018) https:// www.waldeigentuemer.de/ . Accessed 08 April 2019
Andreadis KM, Clark EA, Wood AW, Hamlet AF, Lettenmaier DP (2005) Twentieth-century drought in the conterminous United States. Am Meteorol Soc 6:985-1001. https://doi.org/10.1175/JHM450.1

Auer I, Böhm R, Jurkovic A, Lipa W, Orlik A, Potzmann R, Schöner W, Ungersböck M, Matulla C, Briffa K, Jones P, Efthymiadis D, Brunetti M, Nanni T, Maugeri M, Mercalli L, Mestre O, Moisselin JM, Begert M, Müller-Westermeier G, Kveton V, Bochnicek O, Stastny P, Lapin M, Szalai S, Szentimrey T, Cegnar T, Dolinar M, Gajic-Capka M, Zaninovic K, Majstorovic Z, Nieplova E (2007) HISTALP - historical instrumental climatological surface time series of the greater alpine region. Int J Climatol 27:17-46. https://doi.org/ $10.1002 /$ joc. 1377

Bachmair S, Svensson C, Hannaford J, Barker LJ, Stahl K (2016) A quantitative analysis to objectively appraise drought indicators and model drought impacts. Hydrol Earth Syst Sci 20:2589-2609. https://doi.org/10.5194/hess-20-2589-2016

Badische Neueste Nachrichten (1947a) 53 Tropentage im Sommer 1947: Seit 100 Jahren kein Sommer so heiß und trocken wie 1947. Edition from 04.10.1947(118):3. https://digital.blb-karlsruhe.de/blbz/ periodical/pageview/4707190. Accessed 08 April 2019

Badische Neueste Nachrichten (1947b) Leistungsrückgang durch schlechte Ernährung. Die schwierige Ernährungslage verursacht in Südbaden sinkende Arbeitsmoral. Edition from 04.10.1947 (118):3. https://digital.blb-karlsruhe.de/blbz/periodical/zoom/4707190. Accessed 08 April 2019

Badische Neueste Nachrichten (1949a) Ernteschäden in der Ortenau. Durch Trockenheit, Mäuse- und Wildschweinschäden. Edition from 17.09.1949 (184):6. https://digital.blb-karlsruhe.de/blbz/periodical/ zoom/4711571. Accessed 08 April 2019

Badische Neueste Nachrichten (1949b) Absinken der Grundwasserstände. Teilweise wurden die Tiefstände des Dürresommers 1947 übertroffen. Edition from 19.09.1949 (185):3. Online https://digital.blb-karlsruhe.de/blbz/periodical/zoom/ 4711580. Accessed 08 April 2019

Badisches Ministerium der Finanzen (1948) Zwangsleistungen des Landes Baden aufgrund von Anordnungen der Besatzungsmacht. Stand 31. März 1948. Freiburg

Baumgartner A (1950) Niederschlagsschwankungen und Dürregefährdung mit Bezug auf den Waldbau. Forstw Cbl 69: 636-662. doi: 10.1007/BF01815731

Beguería S, Vicente-Serrano SM (2013) Calculation of the standardised precipitation-evapotranspiration index. CRAN https://cran.rproject.org/web/packages/SPEI/SPEI.pdf

Bender K (1948) Studien über die Massenvermehrung des großen Fichtenborkenkäfers Ips typographus L. aus dem Raum Meßkirch Südbaden während der Jahre 1946 und 1947. Freiburg

Benestad RE (2003) How often can we expect a record event? Clim Res 25:3-13

Blauhut V, Stahl K (2018) Risikomanagement von Dürren in Deutschland: von der Messung von Auswirkungen zur Modellierung. Forum für Hydrologie und Wasserbewirtschaftung 39:203-213. https://doi.org/10.14617/for.hydrol.wasbew.39.18

Blauhut V, Gudmundsson L, Stahl K (2015a) Towards pan-European drought risk maps. Quantifying the link between drought indices and reported drought impacts. Environ Res Lett 10:14008. https:// doi.org/10.1088/1748-9326/10/1/014008

Blauhut V, Stahl K, Kohn I (2015b) The dynamics of vulnerability to drought from an impact perspective. In: Andreu J, Solera A, Paredes-Arquiola J, Haro-Monteagudo D, van Lanen H (eds) Drought - research and science-policy interfacing: proceedings of the international conference on drought: research and science-policy interfacing, Valencia, Spain, 10-13 March 2015. CRC Press, Hoboken, pp 349-354

Blauhut V, Stahl K, Stagge JH, Tallaksen LM, De Stefano L, Vogt J (2016) Estimating drought risk across Europe from reported drought 
impacts, drought indices, and vulnerability factors. Hydrol Earth Syst Sci 20:2779-2800. https://doi.org/10.5194/hess-20-2779-2016

Borcherdt C, Grimm I, Rieger G, Strohal R (1989) Führer durch die Agrarstatistiken der südwestdeutschen Länder 1850-1939, vol 2, St Katharinen

Brázdil R, Dobrovolný P, Trnka M, Kotyza O, Rezníčková L, Valášek H, Zahradníček P, Štěpánek P (2013) Droughts in the Czech lands, 1090-2012 AD. Clim Past 9:1985-2002. https://doi.org/10.5194/ cp-9-1985-2013

Brázdil R, Raška P, Trnka M, Zahradníček P, Valášek H, Dobrovolný P, Řezníčková L, Treml P, Stachoň Z (2016) The central European drought of 1947: causes and consequences, with particular reference to the Czech lands. Clim Res 70:161-178. https://doi.org/10.3354/ cr01387

Brázdil R, Kiss A, Luterbacher J, Nash DJ, Řezníčková L (2018) Documentary data and the study of the past droughts: an overview of the state of the art worldwide. Clim Past 14:1915-1960. https:// doi.org/10.5194/cp-2018-118

Briffa KR, Jones PD, Hulme M (1994) Summer moisture variability across Europe, 1892-1991: an analysis based on the palmer drought severity index. Int J Climatol 14:475-506. https://doi.org/10.1002/ joc. 3370140502

Brooks CEP, Gkasspoole J (1922) The drought of 1921. Q J R Meteorol Soc 48:139-168. https://doi.org/10.1002/qj.49704820205

Cook E, Seager R, Kushnir Y, Briffa KR, Buntgen U, Frank D, Krusic PJ, Tegel W, Van der Schrier G, Andreu-Hayles L, Baillie M, Baittinger C, Bleicher N, Bonde N, Brown D, Carrer M, Cooper R, Čufar K, Dittmar C, Esper J, Griggs C, Gunnarson B, Günther B, Gutierrez E, Haneca K, Helama S, Herzig F, Heussner KU, Hofmann J, Janda P, Kontic R, Köse N, Kyncl T, Levanič T, Linderholm H, Manning S, Melvin TM, Miles D, Neuwirth B, Nicolussi K, Nola P, Panayotov M, Popa I, Rothe A, Seftigen K, Seim A, Svarva H, Svoboda M, Thun T, Timonen M, Touchan R, Trotsiuk V, Trouet VM, Walder F, Ważny T, Wilson R, Zang C (2015) Old world megadroughts and pluvials during the common era. Sci Adv 1. https://doi.org/10.1126/ sciadv. 1500561

Dai A (2011) Drought under global warming. A review. WIREs Clim Change 2:45-65. https://doi.org/10.1002/wcc.81

De Stefano L, Tánago IG, Ballesteros M, Urquijo J, Blauhut V, Stagge JH, Stahl K (2015) Methodological approach considering different factors influencing vulnerability - pan-European scale. DROUGHTR\&SPI Technical Report No 26

Deutscher Wetterdienst in der US-Zone (1947) Bericht der Alliierten. Zusammenfassende Übersicht der Dürreschäden im Sommer 1947. Bad Kissingen

Dürr F (1986) Chronik der Stadt Heilbronn. 741-1895. Unchanged reprint of the 2nd edition of 1926, Stadtarchiv, Heilbronn

Federal Ministry of Food and Agriculture (2018) https://www.bmel.de/. Accessed 08 April 2019

Freiburger Zeitung (1834a) Freiburg 1784-1943. Edition from 20.07.1834 (201):1. https://fz.ub.uni-freiburg.de/show/fz.cgi?cmd= showpic \&ausgabe $=01 \&$ day $=20 \&$ year $=1834 \&$ month $=07 \&$ project $=$ 3\&anzahl=4. Accessed 8 April 2019

Freiburger Zeitung (1834b) Freiburg 1784-1943. Edition from 01.08.1834 (215):2. https://fz.ub.uni-freiburg.de/show/fz.cgi?cmd= showpic \&ausgabe $=01 \&$ day $=01 \&$ year $=1834 \&$ month $=08 \&$ project $=$ 3\&anzahl=4. Accessed 8 April 2019

Freiburger Zeitung (1834c) Freiburg 1784-1943. Edition from 19.08.1834 (231):1. https://fz.ub.uni-freiburg.de/show/fz.cgi?cmd= showpic\&ausgabe $=01 \&$ day $=19 \&$ year $=1834 \&$ month $=08 \&$ project $=$ 3\&anzahl $=4$. Accessed 8 April 2019

Freiburger Zeitung (1834d) Freiburg 1784-1943. Edition from 21.10.1834 (294):1. https://fz.ub.uni-freiburg.de/show/fz.cgi?cmd= showpic\&ausgabe $=01 \&$ day $=21 \&$ year $=1834 \&$ month $=10 \&$ project $=$ 3\&anzahl $=4$. Accessed 8 April 2019
Geiger R (1951) Die Waldgefährdung durch den Dürresommer 1947. Forstw Cbl 70:349-355. https://doi.org/10.1007/BF01821272

Gil-Guirado S, Espín-Sánchez JA, Del Rosario PM (2016) Can we learn from the past? Four hundred years of changes in adaptation to floods and droughts. Measuring the vulnerability in two Hispanic cities. Clim Chang 139:183-200. https://doi.org/10.1007/s10584-016$1768-0$

Glaser R (2013) Klimageschichte Mitteleuropas. 1200 Jahre Wetter, Klima, Katastrophen, 3rd edn. Primus, Darmstadt

Glaser R, Riemann D, Kellersohn A, Lentz S, Hanewinkel C, Beck A, Vogt S, Borel F, Sidawi W, Kahle M, Vogt J, Steller H, Specht S, Koslitz S (2015) Tambora - the climate and environmental history collaborative research environment. https://doi.org/10.6094/ tambora.org

Glaser R, Himmelsbach I, Bösmeier A (2017) Climate of migration? How climate triggered migration from Southwest Germany to North America during the 19th century. Clim Past 13:1573-1592. https://doi.org/10.5194/cp-13-1573-2017

Glaser R, Riemann D, Vogt S, Himmelsbach I (2018) Long- and shortterm central European climate development in the context of vulnerability, food security, and emigration. Leggewie C, Mauelshagen F (ed) climate change and cultural transition in Europe. Climate Cult 4:85-118

González Tánago I, Urquijo J, Blauhut V, Villarroya F, De Stefano L (2016) Learning from experience: a systematic review of assessments of vulnerability to drought. Nat Hazards 80:951-973. https://doi.org/10.1007/s11069-015-2006-1

Guttman NB (1999) Accepting the standardized precipitation index. A calculation algorithm. Journal of the American Water Resources Association 35:311-322. https://doi.org/10.1111/j.1752-1688.1999. tb03592.x

Hannaford J, Buys G, Stahl K, Tallaksen LM (2013) The influence of decadal-scale variability on trends in long European streamflow records. Hydrol. Earth Syst Sci 17:2717-2733. https://doi.org/10. 5194/hess-17-2717-2013

Haslinger K, Holawe F, Blöschl G (2018) Spatial characteristics of precipitation shortfalls in the greater alpine region. A data-based analysis from observations. Theor Appl Climatol 27:1-15. https://doi. org/10.1007/s00704-018-2506-5

Heyn E (1981) Wasser - ein Problem unserer Zeit: Wasser Wasserwirtschaft - Gewässerschutz, 1st edn. Studienbücher Geographie. Diesterweg, Frankfurt a M

Klein J, Nash DJ, Pribyl K, Endfield GH, Hannaford M (2018) Climate, conflict and society: changing responses to weather extremes in nineteenth century Zululand. Environ Hist Camb 24:377-401. https://doi.org/10.3197/096734018X15137949591963

KLIWA (Klimaveränderung und Wasserwirtschaft) (2009) Auswirkung des Klimawandels auf Niedrigwasserverhältnisse in BadenWürttemberg, Bayern und Rheinland-Pfalz Arbeitskreis KLIWA 14

Koppe C, Jendritzky G (2014) Die Auswirkungen von thermischen Belastungen auf die Mortalität. In: Lozán JL, Grassl H, Karbe L, Jendritzky G (ed) Warnsignal Klima: Gefahren für Pflanzen, Tiere und Menschen, 2nd edn. http://www.klima-warnsignale.unihamburg.de/wp-content/uploads/2014/03/koppe_jendritzky.pdf. Accessed 13 December 2018

Kreibich H, Blauhut V, Aerts JCJH, Bouwer LM, Van Lanen HAJ, Mejia A, Mens M, Van Loon AF (2019) How to improve attribution of changes in drought and flood impacts. Hydrol Sci J 64:1-18. https:// doi.org/10.1080/02626667.2018.1558367

Lloyd-Hughes B, Saunders MA (2002) A drought climatology for Europe. Int J Climatol 22:1571-1592. https://doi.org/10.1002/joc. 846

Landesanstalt für Umwelt, Messungen und Naturschutz BadenWürttemberg (2019) $\mathrm{Zu}$ warm, zu heiß, zu trocken? Eine klimatische Einordnung des Jahres 2018 für Baden-Württemberg. Karlsruhe 
McKee T, Doesken NJ, Kleist J (1993) The relationship of drought frequency and duration to time scales. Proceedings of the 8th Conference on Applied Climatology 17:179-183. American Meteorological Society, Boston

Nash DJ, Klein J, Endfield GH, Pribyl K, Adamson GCD, Grab SW (2019) Narratives of nineteenth century drought in southern Africa in different historical source types. Clim Chang 6:467-485. https:// doi.org/10.1007/s10584-018-2352-6

National Drought Mitigation Center (2018) North American Drought Monitor. University of Nebraska-Lincoln, U.S.A., https:// droughtmonitor.unl.edu/nadm/Home.aspx . Accessed 8 December 2018

Nees G, Kehrer H (2002) Alzenauer Wetterchronik. Die interessantesten Wetterereignisse in Alzenau, im Kahlgrund und am Untermain von 265 bis 1999. Keim, Weil der Stadt

Noone S, Broderick C, Duffy C, Matthews T, Wilby RL, Murphy C (2017) A 250-year drought catalogue for the island of Ireland (1765-2015). Int J Climatol 37:239-254. https://doi.org/10.1002/ joc. 4999

Orlowsky B, Seneviratne SI (2013) Elusive drought: uncertainty in observed trends and short- and long-term CMIP5 projections. Hydrol Earth Syst Sci 17:1765-1781. https://doi.org/10.5194/hess-171765-2013

Pfaff K (1846) Geschichte der Stadt Stuttgart nach archival-Urkunden und anderen bewährten Quellen, Vol 2, Stuttgart

Sheffield J, Wood EF, Roderick ML (2012) Little change in global drought over the past 60 years. Nature 491:435-438. https://doi. org/10.1038/nature11575

Spinoni J, Naumann G, Vogt J, Barbosa P (2015) European drought climatologies and trends based on a multi-indicator approach. Glob Planet Chang 127:50-57. https://doi.org/10.1016/j.gloplacha. 2015.01.012

Stagge JH, Tallaksen LM, Kohn I, Stahl K, van Loon AF (2013) A European drought reference (EDR) database: design and online implementation. DROUGHT-R\&SPI deliverable

Stagge JH, Rizzi J, Tallaksen LM, Stahl K (2015) Future meteorological drought: projections of regional climate models for Europe. DROUGHT-R\&SPI Technical Report No 25

Stahl K, Kohn I, Blauhut V, Urquijo J, De Stefano L, Acacio V, Dias S, Stagge JH, Tallaksen LM, Kampragou E, Van Loon AF, Barker LJ, Melsen LA, Bifulco C, Musolino D, de Carli A, Massarutto A, Assimacopoulos D, Van Lanen HAJ (2016) Impacts of European drought events. Insights from an international database of text-based reports. Nat Hazards Earth Syst Sci Discuss 3:801-819. https://doi. org/10.5194/nhessd-3-5453-2015
Svoboda M, Hayes M, Wood D (2012) Standardized precipitation index. User guide. World Meteorological Organization, Geneva

Van der Schrier G, Efthymiadis D, Briffa KR, Jones PD (2007) European alpine moisture variability for 1800-2003. Int J Climatol 27:415427. https://doi.org/10.1002/joc.1411

Van Dijk AIJM, Beck HE, Crosbie RS, de Jeu RAM, Liu YY, Podger GM, Timbal B, Viney NR (2013) The millennium drought in Southeast Australia (2001-2009): natural and human causes and implications for water resources, ecosystems, economy, and society. Water Resour Res 49:1040-1057. https://doi.org/10.1002/wrcr. 20123

Van Lanen HAJ, Laaha G, Kingston DG, Gauster T, Ionita M, Vidal JP, Vlnas R, Tallaksen LM, Stahl K, Hannaford J, Delus C, Fendekova M, Mediero L, Prudhomme C, Rets E, Romanowicz RJ, Gailliez S, Wong WK, Adler MJ, Blauhut V, Caillouet L, Chelcea S, Frolova N, Gudmundsson L, Hanel M, Haslinger K, Kireeva M, Osuch M, Sauquet E, Stagge JH, Van Loon AF (2016) Hydrology needed to manage droughts. The 2015 European case. Hydrol Process 30: 3097-3104. https://doi.org/10.1002/hyp. 10838

Van Loon AF (2015) Hydrological drought explained. WIREs Water 2: 359-392. https://doi.org/10.1002/wat2.1085

Wilhite DA (2000) Drought as a natural hazard: concepts and definitions. In: Wilhite DA (ed) Drought. A global assessment. Routledge, London

Wilhite DA, Glantz MH (1985) Understanding: the drought phenomenon: the role of definitions. Water Int 10:111-120

Wilhite DA, Pulwarty RS (2017) Drought as hazard: understanding the natural and social context. In: Wilhite DA, Pulwarty RS (eds) Drought and Water Crises. Integrating Science, Management, and Policy. Taylor \& Francis Group, Boca Raton, pp 3-20

Württembergisches Jahrbuch für Statistik und Landeskunde (WJB) (1830) Stuttgart, Germany, p. 2 ff., 1830

Zargar A, Sadiq R, Naser B, Khan FI (2011) A review of drought indices. Environ Rev 19:333-349. https://doi.org/10.1139/A11-013

Publisher's note Springer Nature remains neutral with regard to jurisdictional claims in published maps and institutional affiliations. 